\title{
Teachers' strategies on teaching grammar: Facts and expectations of senior high school teachers at Ambon
}

\author{
Threesje Roza Souisa ${ }^{1}$, Lelyemin Yanuarius ${ }^{2}$ \\ ${ }^{1}$ Department of English Education, Pattimura University, Indonesia \\ ${ }^{2}$ SMA Negeri 1 Dobo-PP Aru, Indonesia
}

\section{Article Info \\ Article history: \\ Received Apr 17, 2020 \\ Revised Sep 20, 2020 \\ Accepted Oct 21, 2020}

\section{Keywords:}

Expectations

Facts

Grammar strategies

Senior high schools

\begin{abstract}
This study is aimed at describing the English as a Foreign Language (EFL) senior high schools' teachers' perceptions on grammar teaching; their teaching strategies which are the most and less frequently applied in their classroom practices and the challenges that they have in teaching grammar. Explanatory mixed approaches were conducted involving 63 teachers as the sample population in collecting quantitative data, and five selected teachers as participants for collecting the qualitative data. The findings showed that teachers' perceptions of grammar teaching are based on their conceptual knowledge as they have experienced it and it is based on grammar theories. The teachers applied vary grammar approaches and strategies but they still face with the challenges in teaching grammar such as students' learning styles and less of teaching references.
\end{abstract}

This is an open access article under the CC BY-SA license.

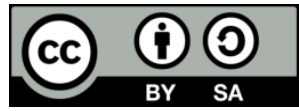

\section{Corresponding Author:}

Threesje Roza Souisa,

Department of English Education,

Pattimura University,

Ambon, Kota Ambon, Maluku, Indonesia.

Email: chocha72souisa@yahoo.com; nauluambon@gmail.com

\section{INTRODUCTION}

As one of the greatest controversial discussion in comprehending English as the foreign language research is grammar teaching [1-3]. Debates on teaching grammar actually focused on the ways whether it is taught implicitly or explicitly and deductively or inductively which is aimed at helping students master it so that they can use it in their communication skill both in oral and written language $[4,5]$. In terms of teaching grammar in English as a Foreign Language (EFL) context, teaching grammar is mainly focused on assisting students to capturedthe pattern of language, and it should be taught in a proper way that students can use it in conversation as in orally and in written forms $[6,7]$. Therefore, helping students to have clear picture of language patterns and its rule are the goal of teaching grammar which aimed at producing practical linguistic [8, 9]. For that reason, in EFL context, grammar translation method is the generally chosen by EFL teachers and as results foreign language learners still facing difficulties in using it into communicative tasks $[10,11]$. Teaching grammar should be done through varied strategies and meaningful activities so that students could figure out the patterns of a target language in which it leads them to apply it in effective ways $[12,13]$. He then briefly stated that "the main function of grammar teaching is to empower the learners to comprehend these sets of rules and so to provide them with the skill of interpretation in the target language." To sum up, students can apply the grammar knowledge to figure out, understand and create purposeful meaning of using the target language in their daily context life and it is believed by the grammar experts that mastering the grammar knowledge and rules is the grindstone for achieving language proficiency [14]. 
In facts, EFL Teachers in senior high schools in Ambon still were used to apply Bahasa as the first language to taught English lesson and it was in line with the principle of using grammar translation method which is necessary to derive the target language meaning. They also applied some strategies/methods with aimed at helping their students to learn and master the ways of language are constructed; presented the grammar patterns \& examples and asked learners to learn and apply them both in spoken and written form. Based on this basic assumption, then the research is conducted for: 1) finding out the EFL senior high schools teachers' perceptions on grammar in their teaching practices, 2) describing teaching grammar teaching approaches and strategies applied by the EFL Senior High teachers in Ambon, 3) identifying the most and less frequently using of teaching grammar strategies in the EFL Senior High teachers in classroom practices, and 4) explaining the EFL Senior High teachers' challenges in teaching grammar.

\section{RESEARCH METHOD}

In conducting the study, explanatory mixed approaches design under the quantitative-qualitative model was applied to collect the data. It is called Mixed research approaches because the quantitative and qualitative data are joined together in collecting the data with the purpose to have complete picture in comprehending the case/situation $[15,16]$. In this kind of explanatory approaches, quantitative data is collected first and it is explored deeply than collecting the qualitative data. The results of quantitative data are used to collect the second data through qualitative way and then continued with analysis and interpretation $[17,18]$. The setting of this study was conducted in all senior high schools in Ambon city and there are 15 state senior high schools and 11 private senior high schools in Ambon city with the number of English teachers is 63 teachers. In distributing the questionnaire to collect the quantitative data, all the English teachers were used as sample population of this study because it is less than 100. Whereas for collecting the qualitative data, five English teachers from 5 districts were chosen with the following qualification; 1) the teacher has teaching experience more than 10-15 years, 2) the teacher had involved in teaching methodology workshops locally and nationally, 3) the teacher is the English instructor and a member of Musyawarah Guru Mata Pelajaran (MGMP).

In gaining all the data, the researchers were the key instrument as it is called as Human Instrument. It meant that the researchers had the important role in collecting the data, analyzing and interpreting the data. Therefore to help the researchers in collecting the data, questionnaire, review documents, in-depth interview, participant classroom observation, and field notes were assigned as the instruments of this study. The questionnaire is used to collect the quantitative data about teachers' grammar teaching strategy and it was distributed to all the English teachers at senior high schools in Ambon city. It was written in English and used Liker's Scale. Review documents in this study refer to English' teachers' lesson plans, their teaching materials (Existing English textbook). In-depth interview was conducted for 5 selected teachers in 5 districts and the interview was conducted by using the Indonesian language with aimed at helping teachers to dig up deeply their ideas, thoughts, and know when they talk in the Indonesian language. To capture all the English teachers' ideas and thoughts on grammar teaching strategy, the recorder was used. Participant classroom observation was necessary to conduct to describe more about their teaching grammar strategy and it was conducted only one time for each teacher. During the classroom observation, field notes were done to write any condition happens in the classroom practices due to teachers' grammar strategy. In regards to quantitative data, the data were analyzed as quantitatively using descriptive quantitative such as percentage. After analyzing quantitative data then it was continued with qualitative data analysis. In analyzing qualitative data, several procedures should be followed starting from collecting data, reducing data, displaying data and drawing conclusion which all the process should be done interactively [19, 20].

\section{RESULTS AND DISCUSSION}

In EFL frame, English grammar instructional still placed as controversy issue whether it should be taught as deductively, inductively, implicit or explicit from time to times. The significant findings from relevance previous studies report that many different perspectives on teaching grammar from foreign language teachers are based on their conceptual and procedural knowledge of English grammar itself. The findings also reflect that the ways of grammar should be taught from teacher to teacher, researcher to researcher and methodologist to methodologist. From the relevance theories, it also described that development of teaching grammar approaches, strategies and methods are varied and it is selected based on the characteristics of the grammar content that be taught. The findings of this study both quantitative and qualitative reveal that the English teachers in Kota Ambon still have good enough clear picture about the concept of grammar, teaching grammar approaches, strategies, and methods as the result of comprehending 
conceptual and procedural knowledge on grammar itself. The following discussions are presented based on the research questions.

\subsection{Teachers' perception of grammar concept in their teaching practices}

Grammar is viewed as the crucial part of learning foreign language and it should be learned and mastered by foreign language students to build good communication. The more they knowing about the ways of language core, the better they keep track the meanings and as result they will use it effectively in communication skills. In line with this, the purpose of teaching grammar is to help students captured the language patterns with aimed at creating practical linguistic [21]. In achieving this goal, it is expected that EFL teachers can enrich their teaching grammar methodology and develop it into their classroom practices based on their conceptual and procedural knowledge.

The research findings from quantitative data reveal that EFL teachers in Ambon City have the various concept of grammar concept and how it is contributed to their teaching grammar approaches, strategies, and methods. The data of distributed questionnaire for 63 English teachers in senior high schools in Ambon show that 58 teachers or $92 \%$ of the teachers understand that grammar is the branch of the language that assist students expresses them. The teachers realize that by awareness in using grammar and helping students to understand grammar itself can encourage them to express their selves by several of ways in English. It is about 61 teachers or $97 \%$ of the teachers have a clear concept of grammar that it is related to organization of pattern of words in sentences. This conceptual idea is implied that utilizing grammar rules in communication is better to convey the message meanings than only knowing the words in the single sentence [22]. This idea describes that the principle goal of a language is to communicate the message in a significant way and the ways students learn it should be done in purposeful ways so that they not only comprehend the grammatical forms but also can apply it in meaningful ways [23].

About 57 teachers or $90 \%$ of the teachers placed their conceptual knowledge on grammar under prescriptive grammar type in which teaching grammar should be focused on using good standard language whether it is right or wrong use in communication. This idea is based on prescriptive grammar type which refers to standard use of language and it is the aim of teaching English under the prescriptive grammar model. From the responses, it can be inferred that the teachers focus on the rules as they should be used, therefore they assume that in certain condition, they apply correct forms but other cases they still deal with wrong forms particularly when they speak with native speakers. On the other hand, 44 teachers or $70 \%$ of the teachers put their conceptual knowledge under descriptive grammar type that presented the ways of language related to kind of English structure that the daily used of native language. This type of grammar attempts to explain the ways of a language used by native speakers in their daily life and avoid to making a judgment about wrong or right usage [23, 24].

Under the traditional grammar type, 49 teachers or $77 \%$ of the teachers believe that in their teaching grammar, it should contain eight different parts of speech formed by noun, verbs, articles, pronouns, prepositions, participles, conjunctions and adverbs. To learn a language, learners should study these eight categories separately and develop rules in accordance with their use in translation. The teachers realize that sometimes don't have background theory in general, they just figure out a language as an object to be instructed [25]. From the discussion of quantitative data, it can be inferred that teachers' conceptual knowledge of grammar is based on some theories related to the type of grammars. Almost EFL senior high school teachers understand the concept of theories under the umbrella of prescriptive grammar, descriptive grammar and traditional grammar. Their responses show that their teaching grammar experiences have already suit with the grammar theories, and it can reflect from their grammar classroom practices. On the contrary, the results of classroom observation for the five selected teachers show that their conceptual knowledge is based on traditional grammar type. They view grammar as the set of rules consist of eight categories such as nouns, verbs, pronouns, prepositions, participles, conjunctions, articles and adverbs, and it is reflected through their teaching grammar materials. As it is pointed out by the traditional grammar experts that this type of grammar is an object to be instructed not as a tool because it doesn't grounded theory. For that reason, using grammar textbooks is essential and usually students learn the grammar structures by remember passages and writing chunks. The five selected teachers mostly use texts to teach grammar point starting with reading a text, identify sentences, find the language use of a text and then make sentences use the standard rules of grammar.

\subsection{Kind of teaching grammar approaches applied by senior high school EFL teachers in Ambon}

In comprehending the concept of teaching grammar approaches whether it should be taught as deductively, inductively, or implicitly and explicitly, or focused on form or meaning, the teachers give vary responses based on their perspectives as the result of their teaching experiences. When teaching grammar as inductively, 52 teachers or $82 \%$ of the teachers understand that in teaching grammar, they should consider 
learner as active processor and producer of a language, 55 teacher or $87 \%$ of the teachers believe that engaging their students to discover a generalized grammar or pattern is a good way to teach grammar, 57 teachers or $90 \%$ of the teachers view grammar as growly and alternating procedures, so it is necessary to consider grammar as learning as sustained activity. 53 teachers or $84 \%$ of the teachers have commitment that it is better to provide students with different illustration of language use and engage students to apply English language in their classroom practices, and 56 teachers or $88 \%$ of the teachers assume that the goal of their grammar instructional is involving students be actively participating in grammar activities. To support this finding, in teaching grammar inductively, teachers should help students consider the patterns and rules of English through varied teaching methods.

On contrary, in teaching grammar as deductively, 55 teachers or $87 \%$ of the teachers place their selves as the main role of grammar lesson activities. 52 teachers or $82 \%$ of the teachers start their grammar class with the presentation of grammar rules and examples. This approach allows teacher to teach grammar by describing grammar rules first then continue to sentences' illustration. In directly, with this way, students can comprehend rules, and continue to apply it in their various sentences $[26,27]$. In regards to teaching grammar as explicitly, 49 teachers or $77 \%$ of the teachers strongly agree that teaching grammar explicitly results in more successful learning of English patterns than teach it implicitly. 57 teachers or $90 \%$ of the teachers have experience in using a communicative process to help their students' mastery grammar well. This result shows that when teachers teach grammar explicitly, they deal with a language and the uses of language that should be placed [6], and teaching grammar explicitly refers to the awareness of grammatical knowledge and rules that can students can master it through classroom instruction [26, 28].

As implicitly, 54 teachers or $85 \%$ of the teachers agree that grammar teaching is more than helping students remember a set of English rules. 54 teachers or $85 \%$ of the teachers understand that the function of grammar teaching is empowering their students to comprehend the set of rules and equip students with the English language skills interpretation. When teaching grammar focused on the form, 53 teachers or $84 \%$ of the teachers point that their grammar teaching is mostly focused on the form which is learners should know and master the grammatical role for a specific formation, 57 teachers or $90 \%$ of the teachers have experience in applying task-bask instruction which is focused on form. This finding shows that when teachers teach grammar focused on form, they start with attract students attention to linguistic forms and encourage students awareness of grammatical aspects. Focus on form' approach suggests drawing learners' thoughts to linguistic forms in the beginning but later when they involve in grammar activities, the focused will be on meaning [29]. Meanwhile, when it is focused on meaning, 52 teachers or $82 \%$ of the teachers have experience in using authentic language. This result supports theory about the characteristics of grammar instruction focused on meaning such as; using contextual language, negotiating meaning in classroom interaction, emphasizing classroom communication, focusing on form activities, as well as doing error correction and explicit language instruction rules.

The discussion of quantitative data shows that EFL teachers in senior high schools in Ambon city use very kind of teaching approaches in which they teach grammar as inductively, deductively, implicit, explicit, focus on form and meaning. The results imply that in some occasions, they teach grammar as inductively or deductively but in other situation, they teach grammar as explicitly or implicitly and focus on form and meaning. Meanwhile, the result of classroom observation and interview, the selected teachers mostly use the inductive approach in which they start with the examples and using authentic language context. In this case, the teachers provide students with many sentences' illustration to show the connection of concept is implemented, engage students to use the target language and encourage them to generalize the rules. Some teachers focused on form while others focused on meaning. For instance, In ET' classroom, she teaches grammar as inductively and focused on meaning and it is proven that her approach can work well because the students can actively involve in the learning process because they can discover rules as competitive in playing a game as one her teaching method.

The results of this study showed that as quantitative data, most EFL teachers in Ambon City preferred to use deductive teaching grammar approach and the results of this study support the previous relevance study conducted [30]. Even though from qualitative data, the finding showed that most selected participants used inductive teaching grammar approach. Teaching grammar inductively less effective than teaching grammar deductively when concerning with the academic success of students and He also noted that learning grammar deductively is more lighten up for adult students and most EFL teachers feel comfortable when they teach grammar deductively [31].

\subsection{The most and less frequently strategies and methods commonly used in their classroom practices}

In identifying the most and less frequently strategies and methods commonly used in teaching grammar, it is arranged based on the highest percentage around $90-100 \%$ as the most common strategies, and the percentage around $70-76 \%$ as the lowest percentage and less frequently as teaching grammar strategies 
and methods in their teaching practices. From the quantitative data results, it is shown the most common strategies and methods used by the teachers are: 1) 62 teachers or $98 \%$ of the teachers apply structural context strategy when explain about language expression of invitation in formal and informal situation, verb word order, and interrogative pronouns; 2) Still, under structural context strategy, 61 teachers or $97 \%$ of the teachers describe memorable holiday, and unforgettable weekend when they teach simple past tense, question formation, form to a verb to do, word order in negation; 3) under structural context strategy, 59 teachers or $94 \%$ of the teachers use answer information questions, such as name, address, phone number, to teach present tense of a verb, to be, possessive adjectives. Meanwhile, 4) 58 teachers or $92 \%$ of the teachers use stories in teaching grammar in terms of delivering the story for students as storyteller, and 5) under structural context strategy, 57 teachers or $90 \%$ of the teachers apply role play a shopping trip to buy a gift for a family member or friend when teaching models, collective nouns, and quantifiers.

Referring the less frequently strategies and methods used by EFL teachers in their classroom, the quantitative data report that: 1) 46 teachers or $73 \%$ of the teachers use structural context strategy in terms of fill out the medical history then role play a medical interview on a visit with a new doctor, to teach present perfect tense, present perfect progressive, and 2) 48 teachers or $76 \%$ of the teachers use a daily weather report and report daily schedules of people when teaching forms of verb to be and idiomatic expressions, habitual present, personal pronoun, and demonstrative adjectives.

Teaching grammar through structural context means teachers present several sentences/situation of illustration to figure out English structures. Those situations describe the contextualizing language and it can be used to help students clarify the meaning of it as well as support students for finding rules of forms through induction way. Students can be participated in the oral presentation as they can solve grammar problem. Meanwhile, teaching grammar through stories can be done through eliciting and illustrating grammar points.

In line with quantitative data, the results of the interview and observation show that the selected teachers use very kind of teaching strategies such as structural context, text, and stories. The strategies can be included in the teaching methods such as contextual teaching and learning, cooperative learning, grammartranslation method, demonstration, Think pair share, total physical response, games, text, and storyteller, role play.

\subsection{The challenges faced by senior high school EFL teachers in teaching grammar}

In terms of the challenges faced by senior high school EFL teachers in teaching grammar, from the qualitative findings show that the most challenging they still face in teaching English as general and in teaching English grammar as particular is the students' characteristics. All the selected participants pointed out that their students have different character and learning style and as results, it influences their attitude on learning English grammar. In grammar classroom activities, students sometimes lack attention and not serious, have no background knowledge of English grammar; they are demotivated in developing their grammar knowledge, lack vocabulary. Another challenging such as they limit of English teaching methodologies references and lack of training dealing with teaching grammar provided by the government. It can't be denied that most students perceive learning English grammar as the most bored learning activity when they learn it in a school. Even the teachers have already applied vary teaching strategies, sometimes they still produce unenjoyably teaching grammar atmosphere.

From the challenges above, then some expectations are proposed to be considered in designing teaching grammar such as: 1) Providing students with varied teaching approaches and methods in teaching grammar by considering their learning styles, their attitudes and perception of English grammar can help EFL teachers create enjoyable and meaningful learning grammar activities; 2) Enriching authentic materials as the supplementary materials which is based students' contextualize life of using the language can help EFL teachers minimize the students' grammar problems; 3) Considering students' preferences and teachers difficulties in teaching English in EFL context can help educators and developers in developing EFL curriculum and EFL teaching materials which match with both students and teachers" needs; 4) Designing any training programs that related to teaching methodology to enrich the teachers' conceptual and practical knowledge on grammar so that they can develop teaching model based on the characteristic of EFL frame.

\section{CONCLUSION}

Teachers' perceptions of grammar teaching are based on their conceptual knowledge as they have experienced it in their classroom practices. The teachers' conceptual knowledge is rooted in grammar theories types such as prescriptive grammar, descriptive grammar and traditional grammar. The use of teaching grammar approaches is varied based on the content of grammar. The approaches such as teaching grammar as deductively (55 teachers), inductively (52 teachers), explicitly (49 teachers), implicitly (57 teachers), 
focused on form (53 teachers) and focused on meaning (52 teachers). In line with grammar teaching strategies, most teachers apply structural context strategy, texts, stories, grammar translation, and cooperative learning strategy. The most strategy used in their classroom practices are structural context strategy and cooperative learning strategy and the less strategy used in their classroom practices is under structural context strategy in term of role-playing the situation.

The challenges faced by the EFL teachers in Ambon are the students' characteristics in terms of their learning style and attitude, limitation of English teaching methodology references and training. The fourth conclusions above represent the facts of senior high school EFL teachers in Ambon city regarding their teaching grammar approaches, strategies, and challenges and it is hoped that by considering this research findings, other further researchers will continue to conduct the similar topic with different areas of studies to have complete picture of teaching grammar in East Indoneisa context.

\section{REFERENCES}

[1] Y. G. Butler, "The implementation of communicative and task-based language teaching in the Asia-Pacific Region,” Annu. Rev. Appl. Linguist., vol. 31, pp. 36-57, Mar. 2011.

[2] R. Kafipour, E. Mahmoudi, and L. Khojasteh, "The effect of task-based language teaching on analytic writing in EFL classrooms," Cogent Educ., vol. 5, no. 1, pp. 1-16, 2018.

[3] R. Shadiev and M. Yang, "Review of studies on technology-enhanced language learning and teaching," Sustainability, MDPI, Open Access Journal, vol. 12, no. 2, pp. 1-22, 2020.

[4] L. Osa-Melero, "The impact of the inductive approach on the learning of Spanish," Electron. J. Foreign Lang. Teach., vol. 14, no. 1, pp. 53-69, 2017.

[5] J. Graus and P. A. Coppen, "The Interface between Student Teacher Grammar Cognitions and Learner-Oriented Cognitions," Mod. Lang. J., vol. 101, no. 4, pp. 643-668, 2017.

[6] R. Ellis, "The definition and measurement of L2 explicit knowledge," Lang. Learn., vol. 54, no. 2, pp. 227-275, 2004.

[7] R. S. Al-Jarrah, “A suggested model of corrective feedback provision,” Ampersand, vol. 3, pp. 98-107, 2016.

[8] H. M. El-dali, "Towards an understanding of the distinctive nature of translation studies," J. King Saud Univ. Lang. Transl., vol. 23, no. 1, pp. 29-45, 2011.

[9] D. Bikowski, "Technology for Teaching Grammar," TESOL Encycl. English Lang. Teach, 1st ed. John Wiley \& Sons, Inc., 2018.

[10] C. Tayjasanant and R. Barnard, "Language teachers' beliefs and practices regarding the appropriateness of communicative methodology: A case study from Thailand," J. Asia TEFL, vol. 7, no. 2, pp. 279-311, 2010.

[11] A. P. R. Howatt and R. Smith, "The history of teaching English as a foreign language, from a British and European perspective," Lang. Hist., vol. 57, no. 1, pp. 75-95, 2014.

[12] C. Becker and J. Roos, "An approach to creative speaking activities in the young learners' classroom," Educ. Inq., vol. 7, no. 1, pp. 9-26, 2016.

[13] P. Jones and H. Chen, "The role of dialogic pedagogy in teaching grammar," Res. Pap. Educ., vol. 31, no. 1, pp. 45-69, 2016.

[14] K. Safford, "Teaching Grammar and Testing Grammar in the English Primary School: The Impact on Teachers and their Teaching of the Grammar Element of the Statutory Test in Spelling, Punctuation and Grammar (SPaG)," Chang. English Stud. Cult. Educ., vol. 23, no. 1, pp. 3-21, 2016.

[15] B. L. Sykes, A. Verma, and B. H. Hancock, "Aligning sampling and case selection in quantitative-qualitative research designs: Establishing generalizability limits in mixed-method studies," Ethnography, vol. 19, no. 2, pp. 227-253, 2018.

[16] J. H. Hitchcock and A. J. Onwuegbuzie, "Developing Mixed Methods Crossover Analysis Approaches," J. Mix. Methods Res., vol. 14, no. 1, pp. 63-83, 2020.

[17] S. Kinn and J. Curzio, "Integrating qualitative and quantitative research methods," J. Res. Nurs., vol. 10, no. 3, pp. 317-336, 2005.

[18] J. Sargeant, "Qualitative Research Part II: Participants, Analysis, and Quality Assurance," J. Grad. Med. Educ., vol. 4, no. 1, pp. 1-3, 2012.

[19] D. Amaratunga, D. Baldry, M. Sarshar, and R. Newton, "Quantitative and qualitative research in the built environment: application of 'mixed' research approach," Work Study, vol. 51, no. 1, pp. 17-31, 2002.

[20] J. Agee, "Developing qualitative research questions: A reflective process," Int. J. Qual. Stud. Educ., vol. 22, no. 4, pp. 431-447, 2009.

[21] J. H. M. van Rijt, P. J. F. de Swart, A. Wijnands, and P. A. J. M. Coppen, "When students tackle grammatical problems: Exploring linguistic reasoning with linguistic metaconcepts in L1 grammar education," Linguist. Educ., vol. 52, pp. 78-88, Aug. 2019.

[22] C. Barajas, A. M. González-Cuenca, and F. Carrero, "Comprehension of texts by deaf elementary school students: The role of grammatical understanding," Res. Dev. Disabil., vol. 59, pp. 8-23, Dec. 2016.

[23] H. Neumann, "Teacher assessment of grammatical ability in second language academic writing: A case study," $J$. Second Lang. Writ., vol. 24, no. 1, pp. 83-107, 2014.

[24] Z. A. Rahman, "The use of cohesive devices in descriptive writing by Omani student-teachers," SAGE Open, vol. 3, no. 4, pp. 1-10, 2013. 
[25] I. Foster, "The future of language learning," Lang. Cult. Curric. vol. 32, no. 3, pp. 261-269, 2019.

[26] H. P. Widodo, "Approaches and procedures for teaching grammar," English Teach. Pract. Crit., vol. 5, no. 1, pp. 122-141, 2006.

[27] P. Lee and H. Lin, "The effect of the inductive and deductive data-driven learning (DDL) on vocabulary acquisition and retention," System, vol. 81, pp. 14-25, Apr. 2019.

[28] M. Tammenga-Helmantel, E. Arends, and E. T. Canrinus, "The effectiveness of deductive, inductive, implicit and incidental grammatical instruction in second language classrooms," System, vol. 45, no. 1, pp. 198-210, 2014.

[29] J. C. Richards, "The changing face of language learning: Learning beyond the classroom," RELC J., vol. 46, no. 1, pp. 5-22, 2015.

[30] R. L. Ugla, M. J. Z. Abidin, and M. N. Abdullah, "The influence of proficiency level on the use and choice of L1/12 communication strategies used by Iraqi EFL students," Int. J. Eval. Res. Educ., vol. 8, no. 1, pp. 127-137, 2019.

[31] K. Sik, "Tradition or modernism in grammar teaching: deductive vs inductive approaches," Procedia - Soc. Behav. Sci., vol. 197, no. 0, pp. 2141-2144, 2015. 